IJMS 26 (1), 1-31 (2019)

How to cite this article:

Al Lami M. F. F., Maelah, R., \& Ghassan, G. (2019). Management accounting information usefulness and cloud computing qualities among small-tomedium enterprises. International Journal of Management Studies, 26(1), 1-31.

\title{
MANAGEMENT ACCOUNTING INFORMATION USEFULNESS AND CLOUD COMPUTING QUALITIES AMONG SMALL-TO- MEDIUM ENTERPRISES
}

\author{
MOHAMMED FADIL FARHAN AL LAMI \\ Gazprom Company, Iraq \\ RUHANITA MAELAH* \\ Centre of Governance Resilience and Accountability, \\ Faculty of Economics and Management, \\ Universiti Kebangsaan Malaysia \\ GHEYATH GHASSAN \\ Warba Company, Iraq \\ *Corresponding Author: ruhanita@ukm.edu.my
}

\begin{abstract}
Small-to-medium enterprises (SMEs) stand to benefit and become competitive by utilizing information and communication technologies. Despite constraints faced by SMEs in adopting management accounting practices, it is imperative that management accounting information (MAI) be utilized to attain effective and efficient business operations. SMEs can benefit from cloud computing through the reduction of operating costs related to new technology adoption. In acknowledging the significance of cloud computing and MAI, this study examined the extent of MAI usefulness and qualities of cloud computing among Malaysian SMEs. Through self-administered questionnaires, a total of 105 respondents' feedback was analyzed. The usefulness of MAI is a result of the availability and importance of each
\end{abstract}


dimension's items (timeliness, aggregation, scope, and integration). The findings also showed that the qualities of cloud computing (agility, assurance, accountability, financial, security and privacy, performance, and usability) can be considered as important; thus indicating the extent of technology utilization among SMEs.

Keywords: Management accounting information, cloud computing, smallto-medium enterprises.

JEL Classification: M410, M150

Received:11/6/2019 Revised: 16/10/2019 Accepted: 30/12/2019 Published: 31/1/2020

\section{Introduction}

Small-to-medium enterprises (SMEs) are new companies which consistently change their business activities, as their work environments are characterized by hyper-competitiveness, change, and technological complexity (Christauskas \& Miseviciene, 2012). SMEs face challenges due to inadequate access to finance and workforce, limitations or incapability in adopting technology, and inadequate information compared with large-sized companies (Ting, 2004). Mohd, Kamarudin, Hassan and Muda (2014) suggested training SMEs on developing self-efficacy to improve their entrepreneurial orientations. Findings by Sidek and Mohamad (2014) indicated that managerial, technical, generic and conceptual competencies positively influence SME growth. It has been acknowledged that SMEs differ from large corporations, especially from the perspective of resource constraints. Even though SMEs are constrained from fully adopting MAI due to their small-scale operations and limited resources, the utilization of MAI is imperative in ensuring that they operate effectively and efficiently (Ahmad, 2013). A study by Ahmad (2012) found that MAI positively impacted SME performance, and that absence of MAI could cause business failure. MAI is defined as a source of information which encompasses financial and non-financial data for a company's own use.

The utilization of information and communication technologies (ICT) enables SMEs to compete with large companies by enhancing their competitiveness and providing real benefits to these firms (Alshamaila, Papagiannidis \& Li, 2013). SMEs can enjoy great advantages through 
cloud computing as it reduces costs related to current technology adoption (Carcary, Doherty \& Conway, 2014). Cloud computing is “... an information technology (IT) service model where computing services (both hardware and software) are delivered on-demand independent of device and/or location" (Marston, Bandyopadhyay, Zhang \& Ghalsasi, 2011). Therefore, SMEs are able to reduce operational activities and focus on their core business as providers to manage its system (Tarmidi, Rasid, Alrazi \& Roni, 2014).

In spite of the advantages and opportunities offered by the cloud, presently, the use of IT in SMEs is understudied and remains unique (Riemenschneider, Harrison \& Mykytyn, 2003). With technological advancements during the past few years, accounting IT is now heading towards Internet-based accounting (Christauskas \& Miseviciene, 2011). Therefore, the adoption of cloud technology by companies has now become a considerable concern for researchers (Ekufu, 2012). Nevertheless, studies in this area remains inadequate, particularly in Malaysia (Tarmidi et al., 2014).

In recognizing the significance of cloud computing and MAI, this paper aims to examine the usefulness of MAI and the qualities of cloud computing among Malaysian SMEs. The significance of SMEs is discussed in the next section. A literature review on MAI and cloud computing is then presented, preceding a discussion on research methodology. Next, data analysis based on the responses received and discussions on the findings are presented before the conclusion.

\section{Significance of SMEs}

SMEs throughout the world have long been recognized as the backbone of any economy and a significant contributor of employment and growth (Lim, 2011). In Malaysia, SMEs have an important role in the nation's industrial development (Arokiasamy \& Ismail 2009; Saleh \& Ndubisi, 2006). According to the Economic Census (2011) released in 2016, SMEs represented $97.3 \%(645,136)$ out of the 662,939 establishments in Malaysia. Meanwhile, the compounded annual growth rate (CAGR) of $8.3 \%$ in, was higher compared to $5.4 \%$ for the overall economy. Consequently, the SMEs contributed $35.9 \%$ of the nation's gross domestic product (GDP), and $65 \%$ and $17.8 \%$ to total employment and exports of the country, respectively. SMEs recorded an increase in the share of GDP contributed by all economic sectors 
for the period 2010-2014, with mining and quarrying (39.3\%), and construction $(28.9 \%)$. The encouraging performance in recent years indicates that SMEs are performing well (SME Annual Report 2014/15). The growth of SMEs in Malaysia is the result of initiatives taken by the Malaysian government which include the New Economic Model, Economic Transformation Program, National Key Economic Areas, Strategic Reform Initiatives, National SME Development Council, SME Master Plan 2012-2020, 10th Malaysia Plan, which are aimed at assisting and providing opportunities for SMEs in the domestic and global markets (Mahmud \& Hilmi, 2014).

\section{Literature Review}

\section{Management Accounting Information Usefulness}

Studies by Gordon and Narayanan (1984) and Chenhall and Morris (1986) have been widely adapted by researchers in the MAI field (e.g. Mia, 1993; Gul \& Chia, 1994; Chong, 1996; Mia \& Clarke, 1999; Chang et al., 2003; Teerooven \& Bhagtaraj, 2008; Mia \& Winata, 2014; Odar, Kavcic \& Jerman, 2015; Ghasemi, Mohamad, Karami, Bajuri, Asgharizade \& Liu, 2016). In line with Gordon and Miller (1976), Gordon and Narayanan (1984) hypothesized that with increasing perception towards environmental uncertainties there will be increasing consideration on the importance of non-financial, ex-ante, and external information. The importance of this notion is agreed by other studies (Dermer, 1973; Ghymn \& King, 1976; Gordon et al., 1978; Larcker, 1981). In Chenhall and Morris (1986), the definition of management accounting system design is associated with perceived usefulness of the information's attributes. The study had utilized four information dimensions (timeliness, aggregation, integration and scope), as summarized in Table 1. It is proposed that MAI characteristics of broad scope, timely, aggregated and integrative are perceived as more useful by managers.

The first dimension of MAI is scope. The MAI's restricted information coverage concentrates on in-house events, historical and financialbased data (Chenhall \& Morris, 1986; Bouwens \& Abernethy, 2000; Tillema, 2005). However, MAI's wide information coverage relates to external economic and non-economic environments; where the information is non-financial and ex-ante (Gordon \& Narayanan, 1984; Naranjo-Gil, 2009; Tillema, 2005). Haedr (2012) surveyed 54 large 
manufacturing companies in Libya. Using descriptive analysis, he adopted the approach that was employed in past studies such as by Abdel-Kader and Luther (2008) and Ismail and King (2007) to account for the usefulness of MAI. This was done by multiplying importance and availability. The findings by Haedr (2012) based on descriptive analysis showed that scope, under the MAI characteristics is perceived as vital and available. Therefore, the Libyan companies perceived that the information was useful for their corporate planning and problemsolving tasks.

Table 1

Information Characteristics

\begin{tabular}{|c|c|}
\hline MAI Dimension & Information Characteristics \\
\hline Scope & $\begin{array}{l}\text { External information } \\
\text { Nonfinancial information } \\
\text { Future-oriented (e.g., probabilistic) }\end{array}$ \\
\hline Timeliness & $\begin{array}{l}\text { Frequency of reporting } \\
\text { Speed of reporting }\end{array}$ \\
\hline Aggregation & $\begin{array}{l}\text { Aggregated by time-period } \\
\text { Aggregated by functional area } \\
\text { Analytical or decision models } \\
\text { (e.g., marginal analysis, DCF, inventory } \\
\text { models) }\end{array}$ \\
\hline Integration & $\begin{array}{l}\text { Precise targets for activities and their } \\
\text { interrelationship within sub-unit } \\
\text { Reporting on intra-sub-unit interactions }\end{array}$ \\
\hline
\end{tabular}

Source: Chenhall and Morris (1986).

The second dimension of MAI is timeliness. According to Chenhall and Morris (1986), managers are able to swiftly respond and make correct decisions through the timeliness of MAI. Timeliness includes reporting frequency and speed as well as furnishing of information whenever it is requested (Chenhall \& Morris, 1986; Choe, 1998, Naranjo-Gil, 2009). Haedr (2012) found that timeliness of MAI is perceived as being vital and available. Gaidienë and Skyrius (2006) reported that all the Lithuanian managers who were interviewed 
perceived that the timeliness of MAI was useful for management, and that they preferred information sources that provided information in a timely manner.

The MAI's third dimension is aggregation. This characteristic is related to the furnishing of data summary; which are functional activity data in accordance with decision models or time frames (Chenhall \& Morris, 1986; Choe, 1998). Managers are provided with functional-level data where information related to the outcome of other functional areas is presented. It also assists the managers to analyze their decision across time (Bouwens \& Abernethy, 2000; Chenhall \& Morris, 1986; Gaidienë \& Skyrius, 2006).

The MAI's fourth dimension is integration. This relates to the coordination and interdependence of the company's various departments (Chenhall \& Morris, 1986; Chia, 1995; Teerooven \& Bhagtaraj, 2008). It is the data of activities undertaken by various departments within the corporation, and the impact of a department's decision on other departments, and overall company performance (Chenhall \& Morris, 1986; Naranjo-Gil, 2009). Details about operation tasks, outcomes and inputs are included in the integrated information (Bouwens \& Abernethy, 2000). For example, it may encompass data of other departments' output such as quantity and type, and financial data (such as revenue and cost) related to the output (Bouwens \& Abernethy, 2000; Tillema, 2005).

The study by Haedr (2012) revealed that when past studies related to MAI examined management accounting system's effective design, they were mostly concentrated on a dimension, or together with other dimensions. The broadly studied dimensions of MAI's scope were either single, or of three dimensions. In the study by Haedr (2012), information related to MAI attributes of being important and available was collected together with every attribute's dimension of integration, timeliness, scope and aggregation. These dimensions were then used to calculate MAI's usefulness. The utilized measurements were in accordance to the instruments established by Chenhall and Morris (1986) and Gordon and Narayanan (1984). The study results of Haedr (2012) showed that the responding firms emphasized on every dimension of the MAI, but with more emphasis given to aggregated 
information. For Libyan large manufacturing corporations, the availability of every characteristic of MAI received quite a low score. The usefulness level seemed to depend largely upon the availability level (Haedr, 2012). Table 2 presents the summary of selected research that used MAI characteristics similar to Chenhall and Morris (1986).

\section{Table 2}

\section{Selected Studies on MAI Characteristics}

\begin{tabular}{|c|c|}
\hline Author (s), year and country & Characteristics of MAI \\
\hline Chenhall and Morris (1986), Australia & $\begin{array}{l}\text { Scope, timeliness, aggregation, } \\
\text { integration }\end{array}$ \\
\hline Mia (1993), Australia & Scope \\
\hline Mia and Chenhall (1994), Australia & Scope \\
\hline Mangaliso (1995), South Africa & Scope, timeliness, and aggregation \\
\hline Chong (1996), Australia & Scope \\
\hline Fisher (1996), Australia & Scope, and timeliness \\
\hline Choe (1998), South Korea & Scope, timeliness and aggregation \\
\hline Tsui (2001), China & Scope, and timeliness \\
\hline Gaidienë and Skyrius (2006), Lithuania & $\begin{array}{l}\text { Scope, timeliness, aggregation, } \\
\text { integration }\end{array}$ \\
\hline Agbejule and Burrowes (2007), Finland & Scope \\
\hline Naranjo-Gil and Hartmann (2007), Spain & Scope \\
\hline Mia and Winata (2008), Australia & Scope \\
\hline Susanto (2010), Indonesia & Scope, and timeliness \\
\hline Mia and Winata (2014), Australia & Scope \\
\hline Odar et al. (2015), Slovenian & Scope, and timeliness \\
\hline Ghasemi et al. (2016), Iran & $\begin{array}{l}\text { Scope, timeliness, aggregation, } \\
\text { and integration }\end{array}$ \\
\hline
\end{tabular}

Source: National SME Development Council (2013). 


\section{Cloud Computing}

Based on previous studies, cloud computing has various definitions. The National Institute of Standards and Technology stated that it is "a model for enabling convenient, on-demand network access to a shared pool of configurable computing resources (e.g., networks, servers, storage, applications, and services) that can be rapidly provisioned and released with minimal management effort or service provider interaction" (Mell \& Grance, 2011). Meanwhile, Buttell's (2010) definition include "moving your computer applications and programs to the Internet rather than your desktop". Low et al. (2011) viewed it as a form of service in computing application such as office software, e-mail and business resource planning, which utilizes resources that are shared by employees or business partners. Therefore, an Internet user could interact and exchange data with other servers simultaneously.

Research and consultancy firms also provide definitions of cloud computing. As an example, "Cloud computing is a style of computing in which scalable and elastic IT-enabled capabilities are delivered as a service to external customers using Internet technologies" (Plummer et al., 2008). Whereas, from the business perspective, cloud computing is defined as encompassing all the main advantages for firms as well as providing the technological attributes, that is IT services "are delivered on-demand to customers over a network in a self-service fashion, independent of device and location users pay for the service as an operating expense without incurring any significant initial capital expenditure" (Marston et al., 2011).

Generally, many cloud computing benefits have been identified, such as cost-effectiveness through lower investment in hardware, less maintenance expenses and reduced electricity usage; flexibility; information security; high availability; capable of handling large data; service availability; data confidentiality assurance; and the removal of data transfer bottlenecks (Ekufu, 2012). The sector that is most aggressive in adopting cloud computing is the SMEs (Taylor et al, 2010). They typically require uncomplicated IT applications and need less IT support than huge corporations. The IT function for the SMEs is usually given to external parties so as to be able to concentrate on their core operations (Christauskas \& Miseviciene, 2011). SMEs use cloud computing because of reduced expenses; concentration on core 
competencies; efforts to improve business processes; the requirements of accessing technology, experts and skills; versatility; enhancement; and political reasons (Lacity et al., 2009). The key reasons for the SMEs to outsource their IT operations are to reduce cost, limit their investments on IT and reduce the risk of not being competitive, and as a tool in managing task overload during peak seasons (Yigitbasioglu et al., 2013). Previous studies identified other advantages of cloud computing as follows:

1. Compliance: The accounting programs that use cloud complied with the various requirements; and this includes the standards of accounting and in-house control (Christauskas \& Miseviciene, 2012).

2. Automatic updates: IT personnel no longer have to be worried about paying for future software and hardware updates. The cloud always works with the latest and best version, as upgrades to new software features are automatically installed and made available to all users (Schumacher, 2011).

3. Easier administration: Web-browser is the only tool needed to access the cloud's accounting tools, and every user has a similar software version (Christauskas \& Miseviciene, 2012).

4. Sharing secure information: In terms of safety in shared information. The cloud is better than the conventional business approach. The cloud provides real-time data backup that leads to reduced loss of data (Dimitriu \& Matei, 2014b).

5. Respond to business changes quickly: It is extremely easy to add software or increase the functions of server in the cloud. Businesses could rapidly access additional resources should they want to have swift business expansion (Christauskas \& Miseviciene, 2011).

6. Try before buy: The cloud provides various applications for businesses and service providers will usually conduct detailed demonstrations and provide free trials. This will help firms to make appropriate decisions (Ionescu et al., 2013).

The cloud service model followed in this study is in accordance with the Service Measurement Index (SMI) which is used to measure cloud computing based on the quality of cloud services designed according to the International Organisation for Standardisation (ISO). It encompasses key performance indicators (KPIs) that furnish a standardized approach to measure and compare services. 
It constitutes seven categories and these include (1) Accountability (2) Agility (3) Service Assurance (4) Expenses (5) Performance (6) Security and privacy. These characteristics illustrate service providers' effectiveness in controlling service access, information and tangible facility from where the service providers operate, and (7) Usability, which conveys the clients' ease in service usage (Garg et al., 2011; Monteiro \& Vasconcelos, 2013; Siegel \& Perdue, 2012).

Balco et al. (2017) conducted a survey to reflect the importance of understanding IT trends and from the client's viewpoints. Balco et al. (2017) found that in all markets in every region that was surveyed, cost was not the most vital consideration for cloud computing services. In fact, their main concern was quality, and security considerations as the determinants that prevented adoption. This was followed by issues on current application/network integration, implementation of policies related to applications to shift to the cloud, issues related to compliance and laws, as well as inadequate visibility in future cost. Findings from Balco et al. (2017) suggests that notably there is a proportion of business people who have refrained themselves from utilizing cloud computing because of security and reliability issues. In fact, the potential reason could be rooted in the culture of organizations.

Similar results were obtained from surveys conducted by Monteiro and Vasconcelos (2013), and Kouatli (2016). In the study by Monteiro and Vasconcelos (2013), the Service Measurement Index Framework (SMI) which is related to 24 attributes and 7 categories was used to obtain feedback from community members on their perception of attributes which they perceived as important for a cloud service provider and their respective weights in the SMI Framework. Monteiro and Vasconcelos (2013) found that the main concerns were performance and security, and privacy. This is a sensible notion as it is compatible with the reality of businesses. While businesses employ cloud computing to improve business profitability and faster market entry, they want their private data to be kept confidential. Other categories of cloud computing quality are accountability, agility, assurance, financial and usability.

Kouatli (2016) examined management best practices on cloud computing quality involving 441 university students covering financial viability, availability, security, and protection with ethics. It 
was found that the links were significant between security and data protection and ethics; in which both were key drivers towards cloud computing. The study had suggested steps to be taken in protecting the system against breach of security and unethical conduct. Shaikh and Sasikumar (2015) employed the trust model that encompassed myriad parameters that are the required dimensions together with cloud security in measuring security strength and computing trust value.

\section{Underpinning Theory}

Resource-based view (RBV) is an influential paradigm in explaining how organizations can achieve competitive advantage using valuable, rare, inimitable and non-substitutable internal resources (Robinson, 2008), as opposed to its positioning in the external environment. MAI is considered to be one of the most valuable sources of information within organizations; and it is used for various internal purposes, such as decision-making, strategic planning, and performance evaluation (Lim, 2011). Hui and Yusof (2010) suggested that MAI usage could assist an organization to achieve competitive advantage over its rivals. In addition, Gaidienë and Skyrius (2006) stressed that MAI enhances functions including decision-making, strategy development, and performance improvement. RBV claims that technical competence and degree of competition are important determinants that affect an organization's decisions regarding its technological capability (Kamyabi \& Devi, 2011). The former is the ability to do any relevant technical functions or volume activity in an organization. This includes the capacity to develop new products, new processes and to effectively operate facilities (Ortega, 2010). By adapting RBV, Truong (2010) argued that cloud computing through its relationship with other valuable resources is able to create and sustain competitive advantage. Rockmann et al. (2014) stated that cloud computing is based on IT capability.

Flack and Dembla (2014) pointed out that cloud computing is an additional resource used by organizations through driving high usage of applications, supporting competitiveness, and reducing the cost of IT operations and maintenance. Nuseibeh (2011) stressed that cloud computing could help organizations by offering an opportunity to better interconnect and collaborate within the organization. RBV is the underpinning theory for this study, which attempts to analyze 
MAI usefulness. MAI is an important resource of an organization, and the quality of cloud computing as one of the technological capabilities that interacts with MAI to achieve competitive advantage.

\section{Methodology}

\section{Population and Sample Selection}

The large number of SMEs in Malaysia makes it impractical to include all SMEs throughout Malaysia in this study. Hence, this study decided to focus on certain geographical areas. Therefore, questionnaires were distributed to SMEs located in Selangor, Kuala Lumpur, and Johor. These three areas had the highest number of SMEs and recorded an estimated total of $279,457 \mathrm{SMEs}$, which represented $43.3 \%$ of the total SMEs according to the Malaysian SME statistics (2011) released in 2016. The study's unit of analysis was SMEs from various industries, while the respondents were owners/managers of SMEs. This was similar to the approach taken in previous studies (Ahmad 2012; Ahmad et al. 2015; Koe et al. 2015; Lybaert, 1998). Stratified random sampling was adopted because there were several different industries in the SME sector. A stratified random sample provides the same chance for all population units to be included in the selected sample, which in turn provides a high level of generalizability (Bryman 2007). Figure 1 gives the definition of SMEs.

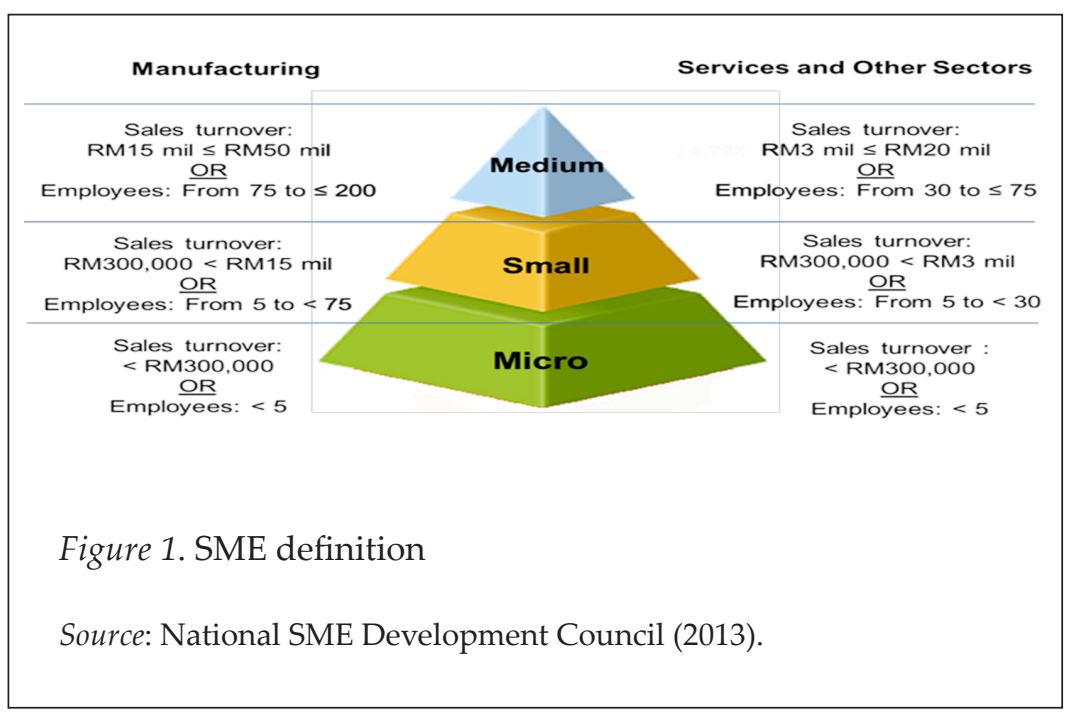




\section{Data Collection}

Self-administered printed questionnaires were used to collect data from the respondents. Keillor et al. (2001) stated that the questionnaire technique is considered to be the most commonly used survey method. Whereas, Moilanen (2001) argued that the questionnaire technique is appropriate for different levels including the organizational level. For each company selected, a questionnaire and an introduction letter specifying the objectives of the study were distributed to the owner/manager. In some situations, the questionnaires were assigned by the companies to the appropriate representatives to respond to the questions. If the respondents were prepared to attend to the questionnaire immediately, the researcher would wait to collect the completed questionnaires. However, if the respondents required some time to answer the questionnaires, the researcher would leave the questionnaires, and return at a later date to collect them. The data collection period spanned over four months.

In total, 384 printed questionnaires were distributed and 105 responses $(27 \%)$ were obtained and usable for analysis. According to Kent (2001) to attain profound results and rational statistical assessment for quantitative analysis, there should be at least 100 responses. The response rate is considered reasonable in this case for the Malaysian environment as the normal rate of response is between 15 percent and 30 percent (Omar \& Ali, 2010).

\section{Variable Measurements}

In relation to the four dimensions of MAI, 19 items were adopted from Haedr (2012). Those were all in Section 1 with items 1 to 6 (scope), items 7 to 10 (timeliness), items 11 to 15 (aggregation) and items 16 to 19 (integration). In this section, all the questions used the five-point scale (two-sided). For MAI importance, the scales were on the left with 1 (not important) to 5 (very important) and for MAI availability, the scales were on the right; ranging from 1 (not available) to 5 (always available). Usefulness under MAI characteristics was perceived as a combination of important and available information.

Cloud Service Measurement Initiative Consortium (CSMIC) has determined several attributes to measure cloud computing services and adopted them in the Service Measurement Index (SMI) (Mohammadkhanli \& Jahani, 2014). SMI allows users to measure 
and compare services provided internally or sourced from external parties. It can be used as a standard method to assist in measuring cloud-based business services (Garg et al., 2011). SMI attributes are designed based on ISO standards. This study utilized seven items of cloud computing service, which were adopted from Monteiro and Vasconcelos (2013). The quality of cloud computing service (QoS) is measured by (SMI), which has been used in previous studies (Garg et al., 2011; Ghani \& Sultan, 2014; Mohammadkhanli \& Jahani, 2014; Siegel \& Perdue, 2012). Using a 5-point Likert scale from 1 (Less important) to 5 (More important), respondents rate the extent of each item being used to assess the quality of cloud computing services provided to their organizations. A similar scale has been used by Garg et al. (2011, 2013) and Siegel \& Perdue (2012). Measurements for both variables are summarized in Table 3 as follows.

Table 3

Measurement of Variables

\begin{tabular}{|c|c|c|c|c|}
\hline Variable & Dimension & Source & Items & Scale \\
\hline \multirow{4}{*}{ MAI } & Scope & & 6 & \multirow{4}{*}{$\begin{array}{l}\text { 5-point scale; the } \\
\text { scale related to the } \\
\text { MAI importance } \\
\text { from (1= not } \\
\text { important, } 5=\text { very } \\
\text { important), while } \\
\text { the scale related to } \\
\text { the MAI availability } \\
\text { from (1= not } \\
\text { available, } 5=\text { always } \\
\text { available). }\end{array}$} \\
\hline & & $\begin{array}{l}\text { Chenhall \& Morris } \\
\text { (1986) and Gordon }\end{array}$ & 4 & \\
\hline & Aggregation & $\begin{array}{l}\text { \& Narayanan } \\
\text { (1984), which }\end{array}$ & 5 & \\
\hline & \multirow[t]{3}{*}{ Integration } & $\begin{array}{l}\text { has been further } \\
\text { modified by Haedr } \\
\text { (2012). }\end{array}$ & 4 & \\
\hline Cloud & & Monteiro and & 7 & 5-point Likert \\
\hline Computing & & Vasconcelos (2013) & & $\begin{array}{l}\text { scale from } 1 \text { (Less } \\
\text { Important) to } 5 \\
\text { (More Important) }\end{array}$ \\
\hline
\end{tabular}

\section{Results}

Demographic information about the SMEs which participated in this study is shown in Table 3. Based on the table, 66.7 percent of the companies were services companies, followed by 25.7 percent manufacturing, 5.7 percent construction, and 1.9 percent agriculture. 
By looking at the number of full-time employees, about 56.2 percent had between 5-29 employees, followed by 21.9 percent with 30-74 employees and 21.9 percent with 75-200 employees. In terms of annual sales turnover, 39 percent raked in between RM3 million to less than RM21 million, followed by 36.2 percent with less than RM3 million and 24.8 percent with between RM21 to RM50 million. The results of the study revealed that 41.9 percent of the organizations have been in the current main industry for between 10 years to less than 20 years, followed by 37.1 percent with more than 20 years, 11.4 percent less than five years, and 9.5 percent with five years to less than 10 years. Table 4 shows the background of the respondents.

Table 4

Demographic Information

\begin{tabular}{|c|c|c|c|}
\hline No. & General information about the company & Frequency & $\%$ \\
\hline \multirow[t]{6}{*}{1} & Main industrial sector of company & & \\
\hline & Services & 70 & 66.7 \\
\hline & Agriculture & 2 & 1.9 \\
\hline & Mining \& Quarrying & 0 & 0.0 \\
\hline & Manufacturing & 27 & 25.7 \\
\hline & Construction & 6 & 5.7 \\
\hline \multirow[t]{4}{*}{2} & Number of full-time employees & & \\
\hline & $5-29$ & 59 & 56.2 \\
\hline & $30-74$ & 23 & 21.9 \\
\hline & $75-200$ & 23 & 21.9 \\
\hline \multirow[t]{4}{*}{3} & Annual sales turnover & & \\
\hline & Less than RM3 million & 38 & 36.2 \\
\hline & RM3 to less than RM21 million & 41 & 39.0 \\
\hline & RM21 to RM50 million & 26 & 24.8 \\
\hline \multirow[t]{5}{*}{4} & $\begin{array}{l}\text { Company age in the current main } \\
\text { industry }\end{array}$ & & \\
\hline & Less than 5 years & 12 & 11.4 \\
\hline & 5 years to less than 10 years & 10 & 9.5 \\
\hline & 10 years to less than 20 years & 44 & 41.9 \\
\hline & More than 20 years & 39 & 37.1 \\
\hline
\end{tabular}




\section{Usefulness of MAI}

For this research, the usefulness of MAI was measured based on its importance and availability. The mean for the usefulness of MAI for every firm is the mean score. The score is obtained through the multiplication of an item's importance scale score with its availability score (i.e. importance*availability). Past research on management accounting used this method such as Haedr (2012) and Ismail and King (2007). The reason is that should the information be available and important, then the manager will perceive it as useful information. However, should the information not be available and not important, or available but not important, then it is not useful information. In summary, to attain the advantages of MAI, two prerequisites must be fulfilled; i.e. availability and importance. Table 5 presents the results of MAI usefulness in accordance with every item's mean score and the mean score for each MAI usefulness dimension (aggregation, timeliness, integration and scope). The mean score was used in the ranking of the group and individual items.

\section{Table 5}

Management Accounting Information (MAI) Usefulness

\begin{tabular}{|c|c|c|c|c|}
\hline & Usefulness & $\begin{array}{c}\text { Rank } \\
\text { Group }\end{array}$ & Mean & Rank Item \\
\hline No. & Scope & & & \\
\hline S1 & $\begin{array}{l}\text { Information that relates to } \\
\text { possible future internal events } \\
\text { (e.g. new projects). }\end{array}$ & 2 & 15.07 & 11 \\
\hline S2 & $\begin{array}{l}\text { Information that relates to } \\
\text { possible future external events } \\
\text { (e.g. customer preferences, } \\
\text { attitudes of government and } \\
\text { consumer bodies, competitive } \\
\text { threats, technological } \\
\text { developments, etc.). }\end{array}$ & 4 & 14.74 & 17 \\
\hline S3 & $\begin{array}{l}\text { Quantification of the likelihood } \\
\text { of future events occurring (e.g., } \\
\text { probability estimates). }\end{array}$ & 6 & 14.47 & 19 \\
\hline
\end{tabular}


IJMS 26 (1), 1-31 (2019)

\begin{tabular}{|c|c|c|c|c|}
\hline & Usefulness & $\begin{array}{l}\text { Rank } \\
\text { Group }\end{array}$ & Mean & Rank Item \\
\hline No. & Scope & & & \\
\hline S4 & $\begin{array}{l}\text { Non-financial information } \\
\text { that relates to production } \\
\text { process (e.g. output rates, scrap } \\
\text { levels, machine efficiency, and } \\
\text { employee productivity). }\end{array}$ & 5 & 14.55 & 18 \\
\hline S5 & $\begin{array}{l}\text { Non-financial information that } \\
\text { relates to product markets (e.g. } \\
\text { market size, market growth). }\end{array}$ & 1 & 15.31 & 9 \\
\hline \multirow[t]{2}{*}{ S6 } & $\begin{array}{l}\text { Information on broad factors } \\
\text { external to your company } \\
\text { (e.g. economic conditions, } \\
\text { population growth, } \\
\text { technological developments, } \\
\text { etc.). }\end{array}$ & 3 & 14.90 & 13 \\
\hline & Mean of the group & & 14.84 & \\
\hline No. & Timeliness & & & \\
\hline $\mathrm{T} 1$ & $\begin{array}{l}\text { Reports are provided } \\
\text { frequently on a systematic, } \\
\text { regular basis (e.g. daily, weekly } \\
\text { reports). }\end{array}$ & 1 & 16.84 & 1 \\
\hline $\mathrm{T} 2$ & $\begin{array}{l}\text { Relevant information is } \\
\text { supplied to managers } \\
\text { automatically upon its receipt } \\
\text { into information systems } \\
\text { or as soon as processing is } \\
\text { completed. }\end{array}$ & 2 & 16.69 & 2 \\
\hline $\mathrm{T} 3$ & $\begin{array}{l}\text { Requested information to arrive } \\
\text { immediately upon request. }\end{array}$ & 3 & 16.55 & 3 \\
\hline $\mathrm{T} 4$ & $\begin{array}{l}\text { There is no delay between } \\
\text { an event occurring (e.g. } \\
\text { competitors' actions, market } \\
\text { demand) and relevant } \\
\text { information being reported to } \\
\text { managers. }\end{array}$ & 4 & 16.38 & 4 \\
\hline & Mean of the group & & 16.61 & \\
\hline
\end{tabular}

(continued) 
No. Aggregation
A1 Information is provided on the different sections or functional areas in your company (e.g. marketing and production, or sales, cost, or profit centres).

A2 Information on the effect of events on particular time periods (e.g. monthly/ quarterly /annual summaries, trends, comparisons).

A3 Information that has been processed to show the influence of events on different functions, such as marketing or production, associated with particular activities or tasks.

A4 Information on the effect of different sections' activities on summary reports (e.g. profit, cost, and revenue reports for other sections).

A5 Information provided in formats suitable for input into decision models (e.g. discounted cash flow analysis, incremental or marginal analysis, inventory analysis, credit policy analysis).

\begin{tabular}{rlrc}
\hline \multicolumn{3}{c}{ Mean of the group } & \multicolumn{1}{c}{15.28} \\
\hline No. $\quad$ Integration & 2 & 14.97 & 12 \\
\hline I1 $\quad \begin{array}{l}\text { Information on precise targets } \\
\text { for the activities of all sections } \\
\text { within your company. }\end{array}$ & 3 & 14.86 & 14 \\
I2 $\quad \begin{array}{l}\text { Information on the impact that } \\
\text { your decisions will have on } \\
\text { other sections in your company. } \\
\text { Information that relates to the } \\
\text { impact that your decisions } \\
\text { would have on the performance } \\
\text { of your whole company. }\end{array}$ & 1 & 15.73 & 5 \\
\hline
\end{tabular}


IJMS 26 (1), 1-31 (2019)

\begin{tabular}{llll}
\hline No. & Integration & & \\
\hline I4 & $\begin{array}{l}\text { Information on the influence of } \\
\text { other individuals' decisions on } \\
\text { your area of responsibility. }\end{array}$ & 4 & 14.82 \\
\hline Mean of the group & 15.10 \\
\hline $\begin{array}{l}\text { Overall mean of the importance of } \\
\text { MAI }\end{array}$ & 15.46 \\
\hline
\end{tabular}

Table 5 shows that all items for the scope dimension seems to be perceived as useful in view that the items' mean scores ranged from 14.47 to 15.31 ; and the group mean is 14.84. "Non-financial information that relates to product markets" was regarded as being the most useful item between all items for the scope dimension. The timeliness of MAI was considered the most useful as the mean score was the highest at 16.61. Meanwhile, the means for the items were between 16.38 and 16.84 . In addition, "reports are provided frequently on a systematic and regular basis" was ranked first, among all items. The mean score was 16.84 .

In addition, the aggregated MAI was recognized as being one of the useful constructs for MAI in the sampled companies and the mean score for the group was 15.28. The items' mean scores in the group ranged from 14.75 to 15.59 . MAI integration recorded a mean score of 15.10, which placed it third after aggregation. "Information that relates to the impact that your decisions would have on the performance of your company as a whole" recorded the highest mean value of 15.73 in the group. Mean values for other items representing integration were between 14.82 and 14.97. Five items with the highest overall mean scores of $16.84,16.69,16.55,16.38$, and 15.73 , respectively are listed as follows:

1. "Reports are provided frequently on a systematic, regular basis (e.g. daily and weekly reports)" (Timeliness).

2. "Relevant information is supplied to managers automatically upon its receipt into information systems or as soon as processing is completed" (Timeliness).

3. "Requested information to arrive immediately upon request" (Timeliness). 
IJMS 26 (1), 1-31 (2019)

4. 'There is no delay between an event occurring (e.g. competitors' actions, market demand) and relevant information being reported to managers" (Timeliness).

5. "Information that relates to the impact that your decisions would have on the performance of the whole company" (Integration).

Four of the items listed above are related to the timeliness of MAI. It can be said that Malaysian SMEs perceived the timeliness of MAI as highly useful. Table 6 provides a summary of mean values on importance, availability and usefulness of MAI among SMEs in Malaysia based on MAI's four dimensions (aggregation, timeliness, integration and scope).

Table 6

Mean Values of Each Dimension

\begin{tabular}{lccc}
\hline Dimension & Importance & Availability & Usefulness \\
\hline Scope & 4.08 & 3.50 & 14.84 \\
Timeliness & 4.25 & 3.65 & 16.61 \\
Aggregation & 4.15 & 3.61 & 15.28 \\
Integration & 4.16 & 3.56 & 15.10 \\
\hline
\end{tabular}

\section{Cloud Computing}

Data presented in Table 7 are the descriptive data on the importance of cloud computing qualities. The mean score is used to rank the extent of each item in assessing the quality of the cloud computing service provider. The results showed that the highest mean was for security and privacy (4.38); indicating that SMEs in Malaysia regarded security and privacy as high important determinants of cloud computing provider's quality. Agility recorded the lowest mean of 3.75. Since each item showed a mean of between 3.75 and 4.38, it indicated that the qualities of cloud computing were considered as important by SMEs in Malaysia and worth applying as a new IT model in their organizations. 
IJMS 26 (1), 1-31 (2019)

Table 7

Descriptive Data on Cloud Computing

\begin{tabular}{|c|c|c|c|c|c|c|}
\hline No. & Cloud Computing & Mean & Median & SD & Min & Max \\
\hline \multicolumn{7}{|c|}{$\begin{array}{l}\text { Rate the quality of cloud computing servic } \\
\text { based on each item: } \\
1 \text { (Less Important) to } 5 \text { (More Important) }\end{array}$} \\
\hline CC1 & $\begin{array}{l}\text { (Accountability): } \\
\text { Can we count } \\
\text { on the provider } \\
\text { organization? }\end{array}$ & 3.91 & 4 & 0.81 & 1 & 5 \\
\hline $\mathrm{CC} 2$ & $\begin{array}{l}\text { (Agility): Can it be } \\
\text { changed and how } \\
\text { quickly? }\end{array}$ & 3.75 & 4 & 0.744 & 2 & 5 \\
\hline CC3 & $\begin{array}{l}\text { (Assurance): How } \\
\text { likely is it that the } \\
\text { service will work as } \\
\text { expected? }\end{array}$ & 4.00 & 4 & 0.784 & 2 & 5 \\
\hline CC4 & $\begin{array}{l}\text { (Financial): How } \\
\text { much is it? }\end{array}$ & 4.08 & 4 & 0.863 & 2 & 5 \\
\hline CC5 & $\begin{array}{l}\text { (Performance): Does it } \\
\text { do what we need? }\end{array}$ & 4.26 & 4 & 0.785 & 2 & 5 \\
\hline CC6 & $\begin{array}{l}\text { (Security } \mathcal{E} \text { Privacy): } \\
\text { Is the service } \\
\text { safe and privacy } \\
\text { protected? }\end{array}$ & 4.38 & 5 & 0.777 & 2 & 5 \\
\hline CC7 & $\begin{array}{l}\text { (Usability): Is it easy } \\
\text { to learn and to use? }\end{array}$ & 4.05 & 4 & 0.801 & 2 & 5 \\
\hline
\end{tabular}

\section{Discussion}

This study aims to determine the usefulness of MAI among SMEs in Malaysia. Despite MAI usefulness being the result of the multiplication of the items' availability and importance, it seems that the usefulness level is more dependent upon the availability degree. Therefore, should there be important and available information, therefore it is useful. From this perspective, every dimension of the MAI can be considered 
as useful for decision-making by the SMEs at a mean value of 15.46; albeit, timeliness as being the most beneficial one. There are limited studies that report descriptive data on the usefulness of MAI. Table 8 shows the mean scores for all four dimensions of MAI usefulness of this study in comparison with findings from Chenhall and Morris (1986) and Haedr (2012).

The mean score for the usefulness of MAI in this study was between 14.84 and 16.61. Haedr (2012) reported a similar mean score of between 13.42 and 15.40 in his study on large manufacturing companies in Libya. Chenhall and Morris (1986) reported a broad range of mean scores of between 10.08 and 24.46 in their study using different manufacturing organizations in Australia with 50-220 employees. Timeliness had the highest mean score in this study (16.61). Meanwhile, Haedr (2012), and Chenhall and Morris (1986) reported the highest mean scores of 15.40 and 24.46 , respectively for aggregation. The lowest mean score for this study (14.84) was for broad scope. This was similar to Haedr (2012) who reported the lowest mean score of 13.42 for broad scope. Meanwhile, the lowest mean score of 10.08 from Chenhall and Morris (1986) was for integration.

Table 8

Mean Score of MAI Usefulness

\begin{tabular}{lccc}
\hline Dimension & Chenhall and Morris (1986) & Haedr (2012) & Present Study \\
\hline Scope & 23.11 & 13.42 & 14.84 \\
Timeliness & 11.73 & 14.62 & 16.61 \\
Aggregation & 24.46 & 15.40 & 15.28 \\
Integration & 10.8 & 14.16 & 15.10 \\
\hline
\end{tabular}

The influence of descriptive data such as industry type, size and age on MAI usefulness and quality of cloud computing among SMEs in Malaysia were not examined in this study. The findings of the descriptive analysis took into consideration the importance, availability and usefulness of MAI (scope, timeliness, aggregation, and integration). The results showed that SMEs asserted on the importance of all MAI characteristics with an overall mean score of 4.16. Here, of the highest importance in this study was derived from 
timeliness of information. Interestingly, the score on availability of MAI was not as high as importance. The availability of MAI was at an acceptable level with a mean score of 3.58. Meanwhile, the broad scope dimension was perceived as being relatively low availability while the availability of timely MAI was higher than other dimensions with a mean score of 3.65 .

The second objective of the study was to determine the importance of cloud computing qualities. The findings showed that the mean value was between 3.75 and 4.38, indicating that cloud computing qualities are important; and that SMEs in Malaysia are likely to benefit from it. The highest mean was for security and privacy at 4.38; while the lowest mean was for agility at 3.75. This suggests that SMEs perceived cloud computing as advantageous. As such, they have potential to implement cloud computing to improve business efficiency. Quality (Balco, 2017); Previous studies on the quality of cloud computing services showed that performance and security (Monteiro \& Vasconcelos, 2013; Kouatli, 2016), and privacy (Monteiro \& Vasconcelos, 2013) as important factors to be considered. The results from the descriptive analysis of this study were not comparable to previous studies that emphasized on adoption (Alshamaila et al., 2013; Amini, 2014; Gupta, Seetharaman \& Raj, 2013) Tarmidi et al., 2014) or previous studies on cloud computing quality (Garg et al., 2013; Monteiro \& Vasconcelos, 2013; Siegel \& Perdue, 2012) that concentrated on the connection between cloud computing and other variables.

From the findings, we can conclude that cloud computing plays a vital role in SMEs in Malaysia through its function in the flow of information and its accessibility to actual and latest information. In addition, it improves business competitiveness for SMEs by reducing the cost load associated with the adoption of modern IT and by being able to focus more on the business. Based on the findings, SMEs in Malaysia should focus on cloud computing adoption to improve access and sharing of information used in their organizations. On another front, this study has provided a vital indication on the extensiveness of technology adoption in Malaysian SMEs.

Results are consistent with previous studies that reported on the role of cloud computing in improving access and sharing of information in real-time; as well as increasing the amount, pace, and capacity of data 
handling that can enhance speed and quality of decision-making in organizations, particularly in SMEs. For example, Quinn et al. (2014) pointed out that cloud computing allows SME managers to access information related to decision-making in new ways, by accessing information at any time using a smart device (tablet or smartphone) at a relatively low cost. Marand et al. (2013) stated that cloud computing plays a vital role in the provision of information through improving information accessibility; analyzing of data; providing continuous auditing; and storing of information. Mia and Winata (2008) argued that use of MAI for decision-making is positively related to cloud computing due to an increase in the capacity of managers to share real-time information instantaneously resulting in more effective decision-making. Also, this study used RBV theory in the area of MAI, to explain MAI as a resource, and cloud computing as a capability to gain competitive advantage.

\section{Conclusion}

This paper has provided empirical evidence concerning the extent of MAI usefulness including the qualities of cloud computing. Every dimension of MAI characteristics (aggregation, timeliness, integration and scope) was perceived as highly useful by the respondents. Similarly, the cloud computing qualities of service providers (financial, accountability, assurance, agility, performance, usability as well as, security and privacy) was perceived as important. The results are expected to assist organizations realizing the significance of MAI in managerial work, and how they can relate a selection of information to the business environment. This could lead to company growth and market competitiveness. Additionally, the results on the role of cloud computing could improve the knowledge of SME managers on the significance of IT, in lieu of competitiveness. Moreover, the SME sector is one of the nation's main industries. The results of this study could provide a vital indication of the extensiveness of cloud computing adoption among Malaysian SMEs, and that it could be utilized in determining the effectiveness of policies as well as the general direction of SMEs and specifically, cloud computing.

Since the sample of the study only consisted of SMEs and is confined to certain geographical areas, the findings could not be generalized to large companies and SMEs of other countries. Consequently, an extension would be to replicate this research in large companies 
or other countries (developing or developed nations). Moreover, this study suffers from a comparatively low response rate in its questionnaire survey due to several reasons (including unwillingness to participate by certain organizations, and cloud computing being a comparatively new technology among SMEs in Malaysia). A combination of self-administered and mail questionnaires could be used to reach out to more respondents.

\section{References}

Abdel-Kader, M., \& Luther, R. (2008). The impact of firm characteristics on management accounting practices: A UK-based empirical analysis. The British Accounting Review, 40(1), 2-27.

Agbejule, A., \& Burrowes, A. (2007). Perceived environmental uncertainty, supply chain purchasing strategy, and use of mas information: An empirical study of finnish firms. Managerial Auditing Journal, 22(9), 913-927.

Ahmad, K. (2012). The use of management accounting practices in Malaysian SMEs. Unpublished Doctoral Dissertation, University of Exeter, United Kingdom.

Ahmad, K. (2013). The adoption of management accounting practices in Malaysian small and medium-sized enterprises. Asian Social Science, 10(2), 236.

Alshamaila, Y., Papagiannidis, S., \& Li, F. (2013). Cloud computing adoption by SMEs in the North East of England: A multiperspective framework. Journal of Enterprise Information Management, 26(3), 250-275.

Amini, M. (2014). The factors that influence on adoption of cloud computing for small and medium enterprises. Unpublished Master Thesis. Universiti Teknologi Malaysia, Malaysia.

Arokiasamy, L., \& Ismail, M. (2009). The background and challenges faced by the small medium enterprises. A human resource development perspective. International Journal of Business and Management, 4(10), 95.

Awasthi, A., \& Varman, R. (2003). Investigating the influence of information technology on decision making. Journal of Advances in Management Research, 1(1), 74-87.

Balco, P., Law, J., \& Drahošová, M. (2017). Cloud market analysis from customer perspective. Procedia Computer Science, 109C, 1022-1027. 
Bouwens, J., \& Abernethy, M. A. (2000). The consequences of customization on management accounting system design. Accounting, Organizations and Society, 25(3), 221-241.

Bryman, A. (2007). Barriers to integrating quantitative and qualitative research. Journal of Mixed Methods Research, 1(1), 8-22.

Buttell, A. E. (2010). 6 reasons to switch to cloud computing. Journal of Financial Planning, 6-7.

Carcary, M., Doherty, E., \& Conway, G. (2014). The adoption of cloud computing by irish SMEs-an exploratory study. Electronic Journal Information Systems Evaluation, 17(1), 3-14.

Chenhall, R. H., \& Morris, D. (1986). The impact of structure, environment, and interdependence on the perceived usefulness of management accounting systems. Accounting Review, 16-35.

Chia, Y. M. (1995). Decentralization, Management Accounting System (MAS) information characteristics and their interaction effects on managerial performance: A Singapore Study. Journal of Business Finance and Accounting, 22(6), 811-830.

Choe, J. M. (1998). The Effects of user participation on the design of accounting information systems. Information $\mathcal{E}$ Management, 34(3), 185-198.

Chong, V.K. (1996). Management accounting systems, task uncertainty and managerial performance: A research note. Accounting, Organizations and Society, 21(5), 415-421.

Christauskas, C., \& Miseviciene, R. (2012). Cloud-computing based accounting for small to medium sized business. Engineering Economics, 23(1), 14-21.

Dermer, J. (1973). Cognitive characteristics and the perceived importance of information. The Accounting Review, July, 511519.

Dimitriu, O., \& Matei, M. (2014). The expansion of accounting to the cloud. SEA-Practical Application of Science, 4, 237-240.

Ekufu, T. K. (2012). Predicting cloud computing technology adoption by organizations: An empirical integration of technology acceptance model and theory of planned behavior.

Flack, C. K., \& Dembla, P. (2014). Influence of cloud-based computing on user productivity. SAIS 2014 Proceedings. 6. http://aisel. aisnet.org/sais2014/6

Gaidienë, Z. \& Skyrius, R. (2006). The usefulness of management accounting information: Users'attitudes. Ekonomika, 74, 21-37.

Garg, S. K., Versteeg, S., \& Buyya, R. (2013). A framework for ranking of cloud computing services. Future Generation Computer Systems, 29(4), 1012-1023. 
Ghasemi, R., Mohamad, N. A., Karami, M., Bajuri, N. H., Asgharizade, E., \& Liu, M. (2016). The mediating effect of management accounting system on the relationship between competition and managerial performance. International Journal of Accounting E Information Management, 24(3), 272-295.

Ghymn, K., \& King, W. (1976). Design of a strategic planning management information system. Omega, October, 595-607.

Gordon, L. A., \& Miller, D. (1976). A contingency framework for the design of accounting information systems. Accounting, Organizations and Society, 1, 59-69.

Gordon, L., Larcker, D., \& Tuggie, F. (1978). Strategic decision processes and the design of accounting systems: Conceptual linkages, Accounting, Organizations and Society, 203-213.

Gordon, L. A., \& Narayanan, V. K. (1984). Management accounting systems, perceived environmental uncertainty and organization structure: An empirical investigation. Accounting, Organizations and Society, 9(1), 33-47.

Gupta, P., Seetharaman, A., \& Raj, J. R. (2013). The usage and adoption of cloud computing by small and medium businesses. International Journal of Information Management, 33(5), 861-874.

Haedr, A. R. (2012). A contingency theory-based investigation of the role of management accounting information in management control systems in large manufacturing companies in Libya. (Unpublished Master Thesis). University of Huddersfield.

Hui, W. S., \& Yusof, N. A. B. M. (2010). The use of Management Accounting Information (MAI): Perceptions of preparers and users. Science and Social Research (CSSR), 2010 International Conference, 259-264.

Ionescu, B., Ionescu, I., Tudoran, L., \& Bendovschi, A. (2013). Traditional accounting vs. cloud accounting. Proceedings of the 8th International Conference on Accounting and Management Information Systems, AMIS, 106-125.

Ismail, N. A., \& King, M. (2007). Factors influencing the alignment of accounting information systems in small and medium sized Malaysian manufacturing firms. Journal of Information Systems and Small Business, 1(1-2), 1-20.

Kamyabi, Y., \& Devi, S. (2011). Using transaction cost economics and resource-based views in management accounting outsourcing: An empirical study of Iranian SMEs. Middle East Journal of Scientific Research, 10(1), 87-98. 
Keillor, B., Owens, D., \& Pettijohn, C. (2001). A Cross-Cultural/CrossNational study of influencing factors and socially desirable response biases. International Journal of Market Research, 43(1), 63-84.

Kent, R. (2001). Data construction and data analysis for survey research. Singapore: Palgrave.

Koe, W.-L., Omar, R., \& Sa'ari, J. R. (2015). Factors influencing propensity to sustainable entrepreneurship of SMEs in Malaysia. Procedia-Social and Behavioral Sciences, 172, 570-577.

Kouatli, I. (2016). Managing cloud computing environment: Gaining customer trust with security and ethical management. Procedia Computer Science, 91, 412-421.

Lacity, M. C., Khan, S. A., \& Willcocks, L. P. (2009). A review of the it outsourcing literature: Insights for Practice. The Journal of Strategic Information Systems, 18(3), 130-146.

Larcker, D. F. (1981). The perceived importance of selected information characteristics for strategic capital budgeting. The Accounting Review, July, 519-528.

Lim, C. F. F. (2011). The relationship between usage of management accounting information and business performance: SMEs in Sabah, Malaysia. (Unpublished Master Thesis). Universiti Malaysia Sabah.

Low, C., Chen, Y., \& Wu, M. (2011). Understanding the determinants of cloud computing adoption. Industrial Management $\mathcal{E}$ Data Systems, 111(7), 1006-1023.

Lybaert, N. (1998). The information use in a SME: Its importance and some elements of influence. Small Business Economics, 10(2), 171-191.

Mahmud, N., \& Hilmi, M. F. (2014). TQM and Malaysian SMEs performance: The mediating roles of organization learning. Procedia-Social and Behavioral Sciences, 130, 216-225.

Mangaliso, M. P. (1995). The strategic usefulness of management information as perceived by middle managers. Journal of Management, 21(2), 231-250.

Marand, A. A., Marand, E. A., \& Dashtebayaz, M. L. (2013). Investigating the effects of cloud computing on accounting and its comparison with traditional models. Advances in Environmental Biology, 7(10 S1), 2836-2847.

Marston, S., Li, Z., Bandyopadhyay, S., Zhang, J., \& Ghalsasi, A. (2011). Cloud computing - the business perspective. Decision Support Systems, 51(1), 176-189. 
Mell, P., \& Grance, T. (2011). The NIST definition of cloud computing. National Institute of Standards and Technology Gaithersburg, 1-7.

Mia, L. (1993). The role of mas information in organisations: An empirical study. The British Accounting Review, 25(3), 269-285.

Mia, L., \& Chenhall, R. H. (1994). The usefulness of management accounting systems, functional differentiation and managerial effectiveness. Accounting, Organizations and Society, 19(1), 1-13.

Mia, L., \& Winata, L. (2008). Manufacturing strategy, broad scope mas information and information and communication technology. The British Accounting Review, 40(2), 182-192.

Mia, L., \& Winata, L. (2014). Manufacturing strategy and organisational performance: The role of competition and MAS information. Journal of Accounting \& Organizational Change, 10(1), 83-115.

Mohd, R., Kamarudin, B. H., Hassan, S., \& Muda, M. (2014). The important role of self-efficacy in determining entrepreneurial orientations of Malay small scale entrepreneurs in Malaysia. International Journal of Management Studies, 20(1), 61-82.

Moilanen, R. (2001). A Learning organization: Machine or human? University of Jyväskylä.

Monteiro, L., \& Vasconcelos, A. (2013). Survey on important cloud service provider attributes using the SMI framework. Procedia Technology, 9, 253-259.

Naranjo-Gil, D., \& Hartmann, F. (2007). Management accounting systems, top management team heterogeneity and strategic change. Accounting, Organizations and Society, 32(7), 735-756.

Nuseibeh, H. (2011). Adoption of cloud computing in organizations. Proceedings of the Seventeen Americas Conference on Information Systems, AMCIS. Detroit, Michigan: AIS Electronic Library (AISeL).

Odar, M., Kavčič, S., \& Jerman, M. (2015). The role of a management accounting system in the decision-making process: Evidence from a post-transition economy. Engineering Economics, 26(1), 84-92.

Omar, M. W., \& Ali, M. N. M. (2010). Brand loyalty and relationship marketing in Islamic banking system/fidélité à la marque et marketing relationnel dans le systeme des banques islamiques. Canadian Social Science, 6(1), 25.

Ortega, M. J. R. (2010). Competitive strategies and firm performance: Technological capabilities' moderating roles. Journal of Business Research, 63(12), 1273-1281. 
Plummer, D. C., Bittman, T. J., Austin, T., Cearley, D. W., \& Smith, D. M. (2008). Cloud computing: Defining and describing an emerging phenomenon. Gartner, June, 17, 1-9.

Quinn, M., Strauß, E., \& Kristandl, G. (2014). The effects of cloud technology on management accounting and decision-making. Financial Management, August, 54-55.

Riemenschneider, C. K., Harrison, D. A., \& Mykytyn, P. P. (2003). understanding it adoption decisions in small business: Integrating current theories. Information \& Management, 40(4), 269-285.

Robinson, S. M. (2008). Understanding the resource-based view: Implications of methodological choice and a new creative context. Unpublished Doctoral Dissertation). PhD thesis, Queensland University of Technology.

Rockmann, R., Weeger, A., \& Gewald, H. (2014). Identifying organizational capabilities for the enterprise-wide usage of cloud computing. Proceedings of the Pacific Asia Conference on Information Systems.

Saleh, A.S., \& Ndubisi, N.O. (2006). An evaluation of SME development in Malaysia. International Review of Business Research Papers, 2(1), $1-14$.

Sidek, Y., \& Mohamad, M. R. (2014) Managerial competencies and small business growth: Empirical evidence from microfinance participants. International Journal of Management Studies, 1(1), 39-59.

Schumacher, W. (2011). Australian accounting firms move into the cloud to administer SMSF. The Australian Journal of Financial Planning, 06(3), 21-25.

SME Corp, Malaysia Secretariat to the National SME Development Council. October, 2013.SMEs, Definitions. Retrieved from http://www.smecorp.gov.my/index.php/en/policies/2015-1221-09-09-49/sme-definition (accessed March 28, 2017). (A)

SME Annual Report 2014/15. SME Corp. Malaysia, Department of Statistics Malaysia.Retrieved from :http://www.smecorp.gov. my/images/Publication/Annual-report/BI/Annual-report-2014. pdf (accessed March 28, 2017). (B)

SME Annual Report 2009/10. National SME Development Council, SME Corp. Malaysia. Retrieved from:http://www.smecorp. gov.my/images/Publication/Annual-report/BI/annual-report2009.pdf (accessed March 28, 2017). (C) 
Shaikha, R., \& Sasikumar, M. (2015). Trust model for measuring security strength of cloud computing service procedia computer science, 45, 380-389.

Siegel, J., \& Perdue, J. (2012). Cloud services measures for global use: The Service Measurement Index (SMI). 2012 Annual SRII Global Conference. 411-415.

Tarmidi, M., Rasid, S. Z. A., Alrazi, B., \& Roni, R. A. (2014). Cloud computing awareness and adoption among accounting practitioners in Malaysia. Procedia-Social and Behavioral Sciences, 164, 569-574.

Taylor, S., Young, A., \& Macaulay, J. (2010). Small businesses ride the cloud: Smb cloud watch-us survey results. Cisco Internet Business Solutions Group, 1-13.

Teerooven, S., \& Bhagtaraj, P. (2008). The effectiveness of management accounting systems: Evidence from functional managers in a developing country. Managerial Auditing Journal, 23(2), 187219.

Tillema, S. (2005). Towards an integrated contingency framework for mas sophistication: Case studies on the scope of accounting instruments in dutch power and gas companies. Management Accounting Research, 16(1), 101-129.

Ting, O. (2004). SMEs in Malaysia: Pivot points for change. Retrieved from http://www. mca. org. my

Truong, D. (2010). How cloud computing enhances competitive advantages: A research model for small businesses. The Business Review, Cambridge, 15(1), 59-65.

Tsui, J. S. (2001). The impact of culture on the relationship between budgetary participation, management accounting systems, and managerial performance: An analysis of Chinese and Western managers. The International Journal of Accounting, 36(2), 125146.

Yigitbasioglu, O. M., Mackenzie, K., \& Low, R. (2013). Cloud computing: How does it differ from it outsourcing and what are the implications for practice and research? The International Journal of Digital Accounting Research, 13(19), 99-121 